\title{
Occurrence and Environmental Features of Heavy Metal Elements of Coal from Coalfield in the Southeast Shanxi
}

\author{
Duan-Le Li, Dong-Min Wang*, Yi-Ren Wang, Cai-Fu Ren and Ning Yuan \\ School of Chemical and Environmental Engineering, China University of Mining and Technology, Beijing 100083, PR China
}

\begin{abstract}
The coal was sampled from No.15 coal seam in coalfield of southeast Shanxi. The $\mathrm{Hg}, \mathrm{As}$, $\mathrm{Se}, \mathrm{Cr}$ and $\mathrm{Pb}$ occurrence in coal seam and environmental features of the heavy metal elements of coal were studied by X-ray fluorescence spectrometry (ARL Quant 'X), X-ray diffraction (XRD) and inductively couple-plasma mass spectrometry (ICP-MS). Environmental features, such as heavy metal element concentration, distribution and occurrence mode, etc., were studied by systematic determination of element concentration, inorganic element and mineral composition in coal. The results showed that the coal from No.15 coal seam had the mercury $(\mathrm{Hg})$ concentration between 0.44 and $0.268 \mu \mathrm{g} / \mathrm{g}$, and average $\mathrm{Hg}$ concentration of $0.11 \mu \mathrm{g} / \mathrm{g}$; arsenic (As) concentration between 0.31 and $0.91 \mu \mathrm{g} / \mathrm{g}, 0.61 \mu \mathrm{g} / \mathrm{g}$ on average; selenium (Se) concentration between 0.94 and $3.56 \mu \mathrm{g} / \mathrm{g}, 2.45 \mu \mathrm{g} / \mathrm{g}$ on average; chromium (Cr) concentration between 9.54 and $24.58 \mu \mathrm{g} / \mathrm{g}, 17.06 \mu \mathrm{g} / \mathrm{g}$ on average; lead $(\mathrm{Pb})$ concentration between 10.23 and $23.56 \mu \mathrm{g} / \mathrm{g}, 18.13$ $\mu \mathrm{g} / \mathrm{g}$ on average. The comparison with the Clark value showed Se was significantly enriched, As and $\mathrm{Cr}$ were lost, and $\mathrm{Hg}$ and $\mathrm{Pb}$ were normal. Compared with the coal from other counties and regions both at home and abroad, as was lost and other elements were normal. The elements irregularly distributed vertically. In spite of different element concentrations in adjacent coal seams, no significant enrichment occurred. The target elements mainly occurred in the form of inorganic matters except As. Hg was mainly concentrated in pyrite and clay minerals. Se, $\mathrm{Cr}$ and $\mathrm{Pb}$ were mainly concentrated in kaolinite, and Se was mainly concentrated in illite. Because of different occurrences or different forms in one mineral, the $\mathrm{Hg}, \mathrm{As}, \mathrm{Se}, \mathrm{Cr}$, and $\mathrm{Pb}$ loss rates were $99.43 \%, 85.91 \%, 77.89 \%, 73.81 \%$, and $68.85 \%$ at $815^{\circ} \mathrm{C}$, respectively.
\end{abstract}

Keywords: Coal ash; Heavy metal elements; Morphological distribution; Environmental features; Loss rate

\section{Introduction}

During coal combustion, heavy metal elements in coal, such as $\mathrm{Hg}$, $\mathrm{Se}, \mathrm{As}, \mathrm{Cr}, \mathrm{Pb}$, etc., migrate into air or concentrate in coal ash, leading to serious harm to human health [1-6]. PECH and Swaine et al. [7,8], expressly listed the heavy metal elements $\mathrm{Hg}$, Se, $\mathrm{As}, \mathrm{Cr}$ and $\mathrm{Pb}$ in coal as key monitored elements. Although coal contains low harmful heavy metal element concentration, usually below $0.5 \mu \mathrm{g} / \mathrm{g}$, it is the main artificial source of harmful heavy metal elements in air because of large coal consumption [9], and these heavy metal elements in coal ash bring countless harm to environment and society. Thus, it is greatly important to study the environmental features of coal, such as heavy metal element concentration, occurrence, etc. and microelements migration and enrichment during combustion [9-13]. Qinshui basin, located in southeast of Shanxi (north latitude: $35^{\circ} \sim 38^{\circ}$, east longitude: $111^{\circ} 00^{\prime} \sim 113^{\circ} 50^{\prime}$ ), is a key coal production place in Northern China, and has rich coal reserves. Although no pollution event about release of harmful heavy metal elements from coal is available in Shanxi, it is found during research that some sensitive elements can be enriched in some coal seams [14], resulting in potential environmental hazards. Herein, No.15 coal seam in the Coalfield in Southeast Shanxi was investigated in this paper. Five elements, $\mathrm{Hg}$, $\mathrm{As}, \mathrm{Se}, \mathrm{Cr}$ and $\mathrm{Pb}$, with big environmental impact were selected to analyze their concentration and morphologic distribution characteristics in the coal ash, study their migration laws and environmental features, in consideration of coal seam petralogy and geochemical composition analysis, obtain their loss rate at $850^{\circ} \mathrm{C}$, and further analyze their migration and enrichment behaviors in coal ash during coal combustion.

\section{Materials and Methods}

\section{Sample collection and preparation}

According to national standard GB/T 482-2008, 20 samples were collected from the coal seam with thickness between 16 and $22 \mathrm{~cm}$ by the continuous channel sampling method. 1\# and 2\# samples were from the roof, and 19\# and 20\# samples were from the floor. 3\# 18\# samples were from the coal seam, with the mass of about $1.5 \mathrm{~kg}$. All the samples were aired, split, ground to 200 mesh $(75 \mu \mathrm{m})$, and then stored in sealed brown wide mouth bottles in a cool place against sunlight for later use.

\section{Methods}

According to GB/T 212-2008, Proximate analysis of coal, the coal samples were industrially tested. The test results are listed in Table 1 . It could be known from Table 1 that 9\#, 10\# and 17\# samples contained gangue in coal seam, and had the high temperature ash (HTA) output ratio of $44.53 \%, 42.67 \%$ and $46.21 \%$, respectively. The coal samples were completely calcined at $815^{\circ} \mathrm{C}$ according to GB/T 30725-2014 in order to determine macroelements in HTA by XRF. The sulphur concentration was determined by a coulomb sulphur analyzer and converted to $\mathrm{SO}_{3}$ concentration.

Raw coal had low inorganic mineral concentration, which was directly determined by XRD. The minerals with the concentration below $3.0 \%$ were difficultly detected. The coal samples were calcined in pure oxygen atmosphere in a tubular furnace for a long time at $370^{\circ} \mathrm{C}$, at which organic components could be effectively removed from raw coal without

*Corresponding author: Dong-Min Wang, School of Chemical and Environmental Engineering, China University of Mining and Technology, Beijing 100083 PR China, Tel: +8615901245174; E-mail: wangdongmin-2008@163.com

Received June 09, 2017; Accepted June 18, 2017; Published June 22, 2017

Citation: Li D, Wang D, Wang Y, Ren C, Yuan N (2017) Occurrence and Environmental Features of Heavy Metal Elements of Coal from Coalfield in the Southeast Shanxi. J Environ Anal Toxicol 7: 483. doi: 10.4172/2161-0525.1000483

Copyright: @ $2017 \mathrm{Li} \mathrm{D}$, et al. This is an open-access article distributed under the terms of the Creative Commons Attribution License, which permits unrestricted use, distribution, and reproduction in any medium, provided the original author and source are credited. 
Citation: Li D, Wang D, Wang Y, Ren C, Yuan N (2017) Occurrence and Environmental Features of Heavy Metal Elements of Coal from Coalfield in the Southeast Shanxi. J Environ Anal Toxicol 7: 483. doi: 10.4172/2161-0525.1000483

Page 2 of 8

\begin{tabular}{|c|c|c|c|c|c|c|c|c|c|c|c|c|c|c|}
\hline \multirow{2}{*}{ No. } & \multicolumn{4}{|c|}{ Proximate analysis } & \multicolumn{10}{|c|}{ Major-element oxides concentration } \\
\hline & $M_{\text {ad }}$ & $A_{\mathrm{d}}$ & $\boldsymbol{V}_{\text {daf }}$ & $\mathrm{FC}_{\mathrm{ad}}$ & $\mathrm{Al}_{2} \mathrm{O}_{3}$ & $\mathrm{SiO}_{2}$ & $\mathrm{Fe}_{2} \mathrm{O}_{3}$ & $\mathrm{~K}_{2} \mathrm{O}$ & $\mathrm{CaO}$ & $\mathrm{Na}_{2} \mathrm{O}$ & $\mathrm{MgO}$ & $\mathrm{P}_{2} \mathrm{O}_{5}$ & $\mathrm{TiO}_{2}$ & $\mathrm{SO}_{3}$ \\
\hline 1 & 1.21 & 93.24 & 16.24 & 9.26 & 34.64 & 56.80 & 0.81 & 2.99 & 0.80 & 1.37 & 1.77 & 0.05 & 0.88 & 1.16 \\
\hline 2 & 1.13 & 72.16 & 13.21 & 4.21 & 34.62 & 55.16 & 4.64 & 2.27 & 0.59 & 1.05 & 1.45 & 0.27 & 1.27 & 2.36 \\
\hline 3 & 0.95 & 16.4 & 11.24 & 0.95 & 33.11 & 54.68 & 0.94 & 2.11 & 3.64 & 1.03 & 1.42 & 0.14 & 0.97 & 1.39 \\
\hline 4 & 0.96 & 8.42 & 11.21 & 0.61 & 34.57 & 53.93 & 1.27 & 2.14 & 3.66 & 1.05 & 1.44 & 0.11 & 3.33 & 1.45 \\
\hline 5 & 0.97 & 8.44 & 10.31 & 0.84 & 34.77 & 55.24 & 1.48 & 2.15 & 1.03 & 1.05 & 1.45 & 0.20 & 1.00 & 1.57 \\
\hline 6 & 0.89 & 8.46 & 11.25 & 0.74 & 34.50 & 55.14 & 1.23 & 2.65 & 7.24 & 1.05 & 1.45 & 0.01 & 1.40 & 1.32 \\
\hline 7 & 0.92 & 8.24 & 11.17 & 0.91 & 34.06 & 53.78 & 1.40 & 2.22 & 4.90 & 1.14 & 1.63 & 0.17 & 1.78 & 1.43 \\
\hline 8 & 0.96 & 8.31 & 11.26 & 0.82 & 34.38 & 47.82 & 3.76 & 2.13 & 0.40 & 1.04 & 1.43 & 1.18 & 1.41 & 1.88 \\
\hline 9 & 0.88 & 44.53 & 15.3 & 3.07 & 32.88 & 50.89 & 1.10 & 2.46 & 1.78 & 1.06 & 1.46 & 0.04 & 1.49 & 1.26 \\
\hline 10 & 0.94 & 42.67 & 14.21 & 2.15 & 35.11 & 41.55 & 1.14 & 2.17 & 0.41 & 1.06 & 1.46 & 0.06 & 1.25 & 1.48 \\
\hline 11 & 0.92 & 8.16 & 11.23 & 0.76 & 34.85 & 55.44 & 1.17 & 2.16 & 0.86 & 1.06 & 1.45 & 0.07 & 1.44 & 1.50 \\
\hline 12 & 0.97 & 7.52 & 11.15 & 0.72 & 33.92 & 55.86 & 1.28 & 2.10 & 5.03 & 1.03 & 1.41 & 0.12 & 1.82 & 1.36 \\
\hline 13 & 0.94 & 7.41 & 11.14 & 0.35 & 33.82 & 55.30 & 2.10 & 2.09 & 2.72 & 1.02 & 1.41 & 0.04 & 1.41 & 1.60 \\
\hline 14 & 0.93 & 6.72 & 11.18 & 0.86 & 32.29 & 54.98 & 4.90 & 2.00 & 7.72 & 0.98 & 1.35 & 0.81 & 0.19 & 1.48 \\
\hline 15 & 0.98 & 7.53 & 11.35 & 0.42 & 31.76 & 50.43 & 1.67 & 1.96 & 9.10 & 0.96 & 1.32 & 0.29 & 1.12 & 1.38 \\
\hline 16 & 0.96 & 8.51 & 11.24 & 0.38 & 30.15 & 55.67 & 1.18 & 1.86 & 16.88 & 0.91 & 1.26 & 0.08 & 1.35 & 1.50 \\
\hline 17 & 0.95 & 46.21 & 14.52 & 4.28 & 37.86 & 55.47 & 1.06 & 0.88 & 1.20 & 1.07 & 1.47 & 0.03 & 1.07 & 1.13 \\
\hline 18 & 0.93 & 8.42 & 11.26 & 0.91 & 25.78 & 54.28 & 2.63 & 0.79 & 22.87 & 0.78 & 1.08 & 1.56 & 1.29 & 1.67 \\
\hline 19 & 1.05 & 67.18 & 12.76 & 6.24 & 34.67 & 56.49 & 3.61 & 2.14 & 0.11 & 1.05 & 1.45 & 0.69 & 1.61 & 1.52 \\
\hline 20 & 1.21 & 87.61 & 18.42 & 7.18 & 34.99 & 55.53 & 1.16 & 2.16 & 0.97 & 1.06 & 1.46 & 0.07 & 1.07 & 1.39 \\
\hline
\end{tabular}

impact on most inorganic minerals [15]. Corundum international standard was added to the low temperature ash (LTA). After that, the samples were scanned by D8 Advance X-ray diffractometer made by Germany Bruker to obtain the XRD spectra, and the minerals in LTA were qualitatively identified by Highscore software based on PDF-2007 database. Figure 1 shows the XRD spectra and main minerals of the samples from the floor. Various minerals were accurately determined by XRD spectra fitting using RockJack system, with the degree of fitting of $0.1583 \%$. Generally, the degree of fitting below $0.2 \%$ showed that the fitting result was relatively reliable [16]. The mineral concentrations were converted to raw coal-based concentrations by LTA output ratio. The results are summarized in Table 2 .

The raw coal samples were digested by ERHOS1 microwave digestion system made by Italy Milestone. The digestion system was $\mathrm{HNO}_{3} / \mathrm{HF}+\mathrm{H}_{3} \mathrm{BO}_{3} .0 .1000 \mathrm{~g}$ of raw coal sample was weighed to a PTFE tank, following by addition of $7 \mathrm{ml}$ of $70 \% \mathrm{HNO}_{3}$ and $1.5 \mathrm{ml}$ of $40 \%$ HF. The obtained sample was heated to $80^{\circ} \mathrm{C}, 140^{\circ} \mathrm{C}$ and $210^{\circ} \mathrm{C}$, i.e., three-stage temperature rise, and primary digested at $210^{\circ} \mathrm{C}$ for $10 \mathrm{~min}$ before cooled to room temperature. $10 \mathrm{ml}$ of $5 \% \mathrm{H}_{3} \mathrm{BO}_{3}$ was added. The sampled was secondarily digested in a microwave digestion system at $150^{\circ} \mathrm{C}$ before $8 \mathrm{ml}$ of $40 \% \mathrm{HNO}_{3} .2 \% \mathrm{HNO}_{3}$ was added till volume. The clear solution was diluted and determined by ICP-MS. $0.0500 \mathrm{~g}$ of HTA sample was added to a PTFE tank. $2 \mathrm{ml}$ of $\mathrm{HF}$ and $10 \mathrm{ml}$ of $\mathrm{HNO}_{3}$ were added before the sample was kept still for $2 \mathrm{~h}$. The sample was stirred until it was completely dissolved. After the revomal of acid, the solution was diluted and determined by ICP-MS. According to the blank and standard sample test data, the quantitative analysis curves for element standards were plotted. According to NIST-1632b and GBW07406, quantitative calculation was performed for the sample. The measured target element concentrations are presented in Table 3.

Hg element was tested by DMA- 80 direct mercury analyzer in such a principle that the solid sample was automatically dried and thermally decomposed in oxygen atmosphere; the decomposition product was catalytically reduced to $\mathrm{Hg}$ atoms in a catalysis tube; $\mathrm{Hg}$ vapor was completely amalgamated in an amalgamation tube; decomposed at high temperature; the carrier gas entrains $\mathrm{Hg}$ vapor to an absorption

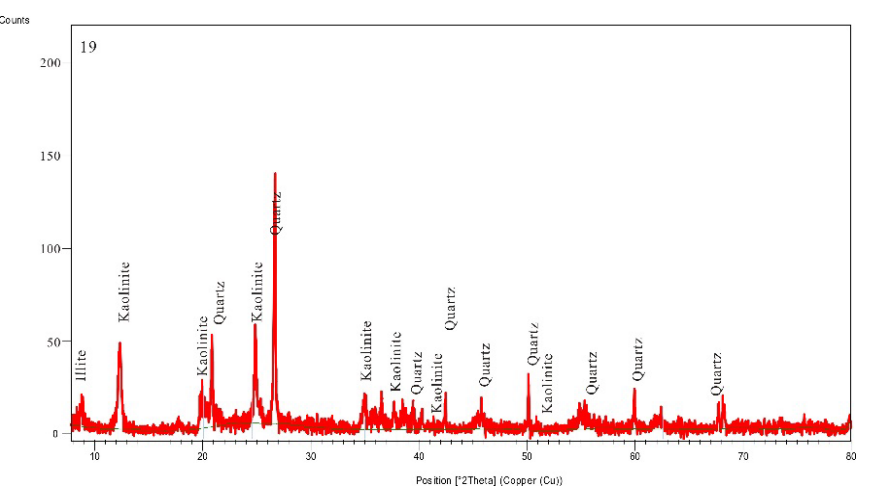

Figure 1: XRD spectra and main minerals of the LTA from the floor.

cell with single wave long path atomic absorption spectrophotometer, where absorption peak height and area of $\mathrm{Hg}$ were determined at 253.7 $\mathrm{nm}$. To avoid sample boat pollution and impact of $\mathrm{Hg}$ residue in the spectrophotometer during determination, a blank test (without sample) was performed before the sample was tested. When the absorbency was below 0.003 and stable, the actual sample could be tested. $0.0500 \mathrm{~g}$ of raw coal sample and HTA sample were put in a quartz boat, which was baked at $650^{\circ} \mathrm{C}$ in a muffle for $30 \mathrm{~min}$ before use in order to eliminate background effect, respectively. The measured $\mathrm{Hg}$ concentrations are listed in Table 3.

\section{Results and Discussion}

\section{Heavy metal element concentration}

The coal from 15\# coal seam in the Coalfield in Southeast Shanxi had $\mathrm{Hg}$ element concentration between 0.044 and $0.268 \mu \mathrm{g} / \mathrm{g}, 0.11 \mu \mathrm{g} / \mathrm{g}$ on average; As element concentration between 0.31 and $0.91 \mu \mathrm{g} / \mathrm{g}, 0.61$ $\mu \mathrm{g} / \mathrm{g}$ on average; Se element concentration between 0.94 and $3.56 \mu \mathrm{g} / \mathrm{g}$, $2.45 \mu \mathrm{g} / \mathrm{g}$ on average; $\mathrm{Cr}$ element concentration between 9.54 and 24.58 $\mu \mathrm{g} / \mathrm{g}, 17.06 \mu \mathrm{g} / \mathrm{g}$ on average; $\mathrm{Pb}$ element concentration between 10.23 and $23.56 \mu \mathrm{g} / \mathrm{g}, 18.13 \mu \mathrm{g} / \mathrm{g}$ on average. The average heavy metal element 
Citation: Li D, Wang D, Wang Y, Ren C, Yuan N (2017) Occurrence and Environmental Features of Heavy Metal Elements of Coal from Coalfield in the Southeast Shanxi. J Environ Anal Toxicol 7: 483. doi: 10.4172/2161-0525.1000483

Page 3 of 8

\begin{tabular}{|c|c|c|c|c|c|c|c|c|c|c|c|}
\hline $\begin{array}{c}\text { Sample } \\
\text { No. }\end{array}$ & $\begin{array}{l}\text { LTA } \\
\text { output } \\
\text { ratio }\end{array}$ & Kaolinite & Illite & Montmorillonite & Quartz & Calcite & Dolomite & Pyrite & $\begin{array}{l}\text { White } \\
\text { Mica }\end{array}$ & Siderite & Anatase \\
\hline 1 & 94.56 & 48 & 21 & 6.1 & 18.7 & 0.2 & & & & & 0.4 \\
\hline 2 & 88.24 & 34 & 26 & 4.7 & 22.1 & 1.1 & & & & & 0.3 \\
\hline 3 & 31.26 & 17 & 7 & 1.7 & 4.1 & & & 0.6 & & 0.2 & 0.7 \\
\hline 4 & 26.21 & 10 & 9 & 1.9 & 3.4 & 0.7 & 0.4 & & & & 0.6 \\
\hline 5 & 26.75 & 11 & 11 & 1.2 & 1.2 & 1.2 & & & 0.7 & & 0.2 \\
\hline 6 & 26.53 & 13 & 6 & 0.4 & 6.3 & & & 0.4 & & & 0.4 \\
\hline 7 & 25.64 & 9 & 12 & 2.1 & 1.8 & 0.7 & & & & & \\
\hline 8 & 25.84 & 12 & 4 & 2.4 & 4.6 & 1.6 & 0.8 & & 0.1 & & 0.3 \\
\hline 9 & 58.46 & 32 & 14 & 3.4 & 6.8 & 1.2 & & 0.6 & & 0.4 & 0.1 \\
\hline 10 & 56.48 & 28 & 13 & 1.5 & 8.4 & 2.5 & & 1.6 & & 0.3 & 1.2 \\
\hline 11 & 31.56 & 20 & 7 & 1.5 & 2.1 & 0.2 & 0.1 & & & & 0.7 \\
\hline 12 & 24.68 & 10 & 6 & 0.5 & 7.4 & 0.1 & & & 0.2 & & 0.5 \\
\hline 13 & 21.42 & 8 & 10 & 1.7 & 1.5 & 0.1 & & & & & 0.1 \\
\hline 14 & 16.22 & 10 & 2 & 1.2 & 2.5 & 0.3 & & & & & 0.2 \\
\hline 15 & 10.51 & 5 & 2 & 0.8 & 1.2 & 1.3 & 0.1 & & & & 0.1 \\
\hline 16 & 19.54 & 13 & 1 & 1.8 & 3.4 & 0.1 & & & & & 0.2 \\
\hline 17 & 53.27 & 27 & 16 & 1.6 & 7.5 & 0.3 & & 0.1 & & 0.2 & 0.6 \\
\hline 18 & 24.16 & 12 & 4 & 0.8 & 6.2 & 0.5 & 0.3 & & & & 0.4 \\
\hline 19 & 75.26 & 26 & 33 & 1.6 & 13.4 & 1 & & & & & 0.3 \\
\hline 20 & 85.29 & 42 & 30 & 1.2 & 10.5 & 0.8 & 0.2 & & 0.1 & & 0.5 \\
\hline
\end{tabular}

Table 2: Mineral Analysis. Unit: \%

\begin{tabular}{|c|c|c|c|c|c|c|c|c|c|c|}
\hline \multicolumn{6}{|c|}{ Raw coal } & \multicolumn{5}{|c|}{ HTA } \\
\hline No. & $\mathrm{Hg}$ & As & $\mathrm{Se}$ & $\mathrm{Cr}$ & $\mathrm{Pb}$ & $\mathrm{Hg}$ & As & Se & $\mathrm{Cr}$ & $\mathrm{Pb}$ \\
\hline 1 & 0.044 & 0.41 & 0.94 & 23.60 & 17.29 & 0.003 & 0.28 & 0.46 & 15.2 & 15.26 \\
\hline 2 & 0.065 & 0.52 & 1.16 & 20.52 & 18.41 & - & 0.25 & 1.29 & 13.12 & 19.66 \\
\hline 3 & 0.177 & 0.31 & 2.83 & 16.23 & 22.54 & 0.004 & 0.21 & 2.62 & 22.52 & 24.64 \\
\hline 4 & 0.071 & 0.46 & 2.74 & 18.24 & 19.48 & - & 0.22 & 2.56 & 23.21 & 23.02 \\
\hline 5 & 0.089 & 0.72 & 2.76 & 17.51 & 16.52 & - & 0.3 & 2.59 & 22.25 & 18.75 \\
\hline 6 & 0.104 & 0.88 & 2.18 & 13.16 & 14.36 & 0.007 & 0.35 & 2.5 & 21.33 & 19.68 \\
\hline 7 & 0.102 & 0.64 & 2.57 & 13.35 & 12.02 & 0.002 & 0.27 & 2.51 & 21.1 & 21.96 \\
\hline 8 & 0.085 & 0.63 & 2.94 & 12.46 & 18.94 & - & 0.23 & 2.59 & 19.26 & 22.66 \\
\hline 9 & 0.174 & 0.36 & 3.31 & 24.58 & 26.15 & - & 0.22 & 2.67 & 23.24 & 28.95 \\
\hline 10 & 0.268 & 0.55 & 3.56 & 22.34 & 23.56 & - & 0.22 & 2.63 & 22.41 & 26.88 \\
\hline 11 & 0.131 & 0.89 & 2.94 & 18.55 & 19.20 & 0.004 & 0.33 & 2.55 & 20.2 & 24.16 \\
\hline 12 & 0.092 & 0.76 & 2.62 & 17.52 & 17.61 & 0.001 & 0.29 & 2.54 & 19.13 & 23.85 \\
\hline 13 & 0.101 & 0.72 & 2.27 & 9.86 & 16.55 & - & 0.25 & 2.54 & 18.29 & 22.56 \\
\hline 14 & 0.082 & 0.78 & 2.00 & 11.77 & 10.23 & - & 0.28 & 2.53 & 19.81 & 19.84 \\
\hline 15 & 0.085 & 0.70 & 2.13 & 9.54 & 10.56 & 0.001 & 0.28 & 2.55 & 19.11 & 20.26 \\
\hline 16 & 0.093 & 0.42 & 2.41 & 16.79 & 19.42 & - & 0.23 & 2.52 & 21.21 & 23.25 \\
\hline 17 & 0.126 & 0.91 & 2.94 & 20.11 & 21.84 & 0.006 & 0.36 & 2.6 & 26.52 & 25.27 \\
\hline 18 & 0.098 & 0.50 & 2.52 & 17.01 & 18.10 & 0.002 & 0.21 & 2.58 & 24.87 & 24.24 \\
\hline 19 & 0.099 & 0.56 & 2.01 & 19.28 & 20.49 & - & 0.22 & 1.31 & 14.02 & 26.34 \\
\hline 20 & 0.074 & 0.44 & 2.24 & 18.73 & 19.26 & 0.001 & 0.22 & 1.29 & 12.56 & 15.88 \\
\hline
\end{tabular}

Table 3: Heavy metal element concentrations in raw coal and ash $(\mu \mathrm{g} / \mathrm{g})$.

concentrations and Clark value in coal seam in Zhang Village Mine, the heavy metal element concentrations of the coals from China, USA and other countries and regions are comparatively listed in Table 4 in order to study the heavy metal elements enrichment in $15 \#$ coal seam. In comparison of the concentrations and Clark values of five heavy metal elements in coal seam in Zhang Village Mine, $\mathrm{Hg}$, As, $\mathrm{Se}, \mathrm{Cr}$, and $\mathrm{Pb}$ element enrichment coefficients were $1.38,0.34,49.00,0.17$, and 1.45 $\mu \mathrm{g} / \mathrm{g}$, respectively. The analysis showed that for earth crust, As and $\mathrm{Cr}$ were lost; $\mathrm{Hg}$ and $\mathrm{Pb}$ concentrations are normal; Se was enriched. In comparison of target element concentrations in the coals from China, USA and other countries and regions, $\mathrm{Hg}, \mathrm{Se}, \mathrm{Cr}$, and $\mathrm{Pb}$ concentrations were normal, and as was lost in 15\# coal seam in the Coalfield in Southeast Shanxi.

\section{Vertical distribution characteristics of sensitive heavy metal elements}

The component sources were very distinct in different phases during peat accumulation. The vertical distribution of heavy metal element concentrations was varied in the coal seam. For example, the undeformed coals from different layers of Yanzhou Coalfield displayed different element concentrations, such as $\mathrm{Cu}, \mathrm{Zn}, \mathrm{Pb}$, etc. [17] When the coal bearing formation underwent tectogenetic movement and 
Citation: Li D, Wang D, Wang Y, Ren C, Yuan N (2017) Occurrence and Environmental Features of Heavy Metal Elements of Coal from Coalfield in the Southeast Shanxi. J Environ Anal Toxicol 7: 483. doi: 10.4172/2161-0525.1000483

\begin{tabular}{|c|c|c|c|c|c|}
\hline Countries/Regions & $\mathbf{H g}$ & $\mathbf{A s}$ & $\mathbf{S e}$ & $\mathbf{C r}$ & $\mathbf{P b}$ \\
\hline Southeast Shanxi & 0.11 & 0.61 & 2.45 & 17.06 & 18.13 \\
\hline Clark value & 0.08 & 1.8 & 0.05 & 100 & 12.5 \\
\hline Global & 0.10 & 5 & 3 & 20 & 25 \\
\hline China & 0.22 & 4.7 & 2 & 16 & 14 \\
\hline USA & 0.17 & 24.0 & 2.47 & 15 & 11.0 \\
\hline Australia & 0.10 & 1.5 & 12 & 12 & $10 \sim 15$ \\
\hline Ukraine & 0.02 & 80 & 1.8 & 15 & 10 \\
\hline India & - & - & - & 35 & 10 \\
\hline Northern China & 0.17 & 3 & 6 & 16 & 20 \\
\hline Huainan-Huaibei mining area & - & 5.53 & 5.5 & 34.47 & 15.81 \\
\hline Enrichment coefficient & 1.38 & 0.34 & 49.00 & 0.17 & 1.45 \\
\hline
\end{tabular}

Table 4: Average heavy metal element concentration of coal from Southeast Shanxi and other countries/regions $(\mu \mathrm{g} / \mathrm{g})$.

deterioration and its associated kinetic heat effect, the heavy metal elements in it would migrate. Li Yunbo found during his study on Coalfield in Northern Anhui Province that $\mathrm{Pb}$, Cr, etc. glomerated with deformation of deformed coals [14]. This study focused on different layers in one coal seam, with consistent undeformed macrographic ingredient structure, but many layers of baulk in the coal seam, and complicated heavy metal element distribution in the coal seam.

Figure 2 shows the vertical distribution of five harmful metal elements concentrations in 15\# coal seam in the Coalfield in Southeast Shanxi. Different layers in one coal seam had significantly different heavy metal element concentrations. Hg element was significantly lost in the roof and floor, but significantly enriched in the baulk layer, and $\mathrm{Hg}$ concentration in each coal seam was not very different; As element was slightly lost in the roof and floor, its concentration was high in the ingredient layer in addition to the baulk layer. For example, as concentration reached $0.88 \mu \mathrm{g} / \mathrm{g}$ in 6 \# sample; Se element concentration was significantly lost in the roof, not very different in other layers, and high, $3.59 \mu \mathrm{g} / \mathrm{g}$, in 10\# sample from baulk layer; Cr element was enriched in the coal seam roof, and its concentration was high in the baulk layer. For example, Cr element concentration was 24.58 and 2234 $\mu \mathrm{g} / \mathrm{g}$ in 9\# and 10\# samples, respectively; Pb element concentration was high in the baulk layer, but it was not different in other layers. In spite of significant difference in some element concentrations in the adjacent layers, such as $\mathrm{Hg}$ concentration of 0.268 and $0.131 \mu \mathrm{g} / \mathrm{g}$ in $10 \#$ and $11 \#$ samples, and as concentration of 0.42 and $0.91 \mu \mathrm{g} / \mathrm{g}$ in 16\# and 17\# samples, they were not significantly enriched. There was no law of $\mathrm{Hg}$, $\mathrm{As}, \mathrm{Se}, \mathrm{Cr}$ and $\mathrm{Pb}$ distribution in each layer in 15\# coal seam.

\section{Occurrence analysis}

It is very difficult to study the occurrence modes of heavy metal elements because of very low heavy metal element concentrations in coal and different heavy metal element occurrences in the coal from different origins or in different coal forming periods. The methods for research on the occurrence modes of heavy metal elements mainly include sequential chemical extraction process, electron microscope and energy spectrum analysis, etc., and correlation between micro element and inorganic element or minerals. Different regions had different micro element occurrence. For example, Finkelman found during sink float experiment, combustion experiment and mineralogy that $\mathrm{Hg}$ mainly occurred in inorganic minerals, and Se was related to organic substances, and believed that Se could occurred in pyrite in place of sulphur and $\mathrm{Pb}$ mainly occurred in sulfide or sulfide-related minerals, and usually in galenite $(\mathrm{PbS})[18,19]$. Dvornikov found during his study on the coal from Donbass in Ukraine that most Hg occurred in the form of soluble solid in pyrite [20]. Zhang et al. proposed during their

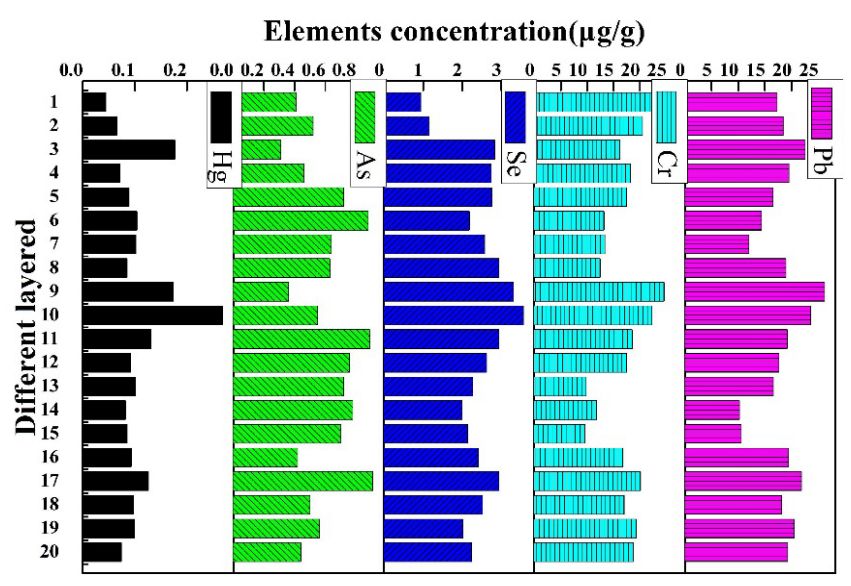

Figure 2: Distribution of heavy metal elements in different layers.

study on $\mathrm{Hg}$ distribution characteristics in main associated minerals in the coal seam in Southwest Guizhou that clay mineral contained Hg, and calcite from hydrothermal origin contained $\mathrm{Hg}$, etc. [21]; Wang found during his sinkfloat experiment that $\mathrm{Cr}$ related to organic matter and clay [22]; Zhao found during his study on Shanxi Coalfield that $\mathrm{Pb}$ mainly entered the organic matters in the coal and crystal lattices in clay minerals when the coal contained no $\mathrm{Pb}$ sulfide [23]; Dai et al. found that $\mathrm{Se}$ and $\mathrm{Pb}$ in the coal from Haer Wusu open-cast mainly occurred in clausthalite; $\mathrm{Se}, \mathrm{Pb}$ and $\mathrm{Hg}$ related to $\mathrm{Pb}$ mineral Zhungeer Coalfield, and $\mathrm{As}$ and $\mathrm{Hg}$ in dias coal mainly occurred in getchellite [24-26]. Thus, micro element occurrence was very complicated.

As an indirect statistical method to study the element occurrence in coal, multivariate statistical analysis has been extensively used in research in recent years [3,27-29]. According to the correlation coefficients among elements in coal, ash and macroelements, the element occurrence in coal was identified by this method in consideration of macroelement occurrence in coal.

Figure 3 shows the relationship between five heavy metal element concentrations in coal seams and ash output ratio. As shown in Figure 3, except As, the other element concentrations are positively correlated with ash output ratio. It can be concluded that $\mathrm{Hg}, \mathrm{Cr}, \mathrm{Se}$, and $\mathrm{Pb}$ in coal seams mainly occurred in the form of inorganic matters.

Table 5 listed the correlation coefficients between inorganic macroelements and between inorganic macroelement and target element in coal. The inorganic elements $\mathrm{Al}, \mathrm{Si}, \mathrm{K}, \mathrm{Na}$, and $\mathrm{Mg}$ had the correlation coefficient between 0.72 and 0.98 , indicative of high correlativity, and mainly occurred in the form of aluminosilicate (clay mineral) in coal; the correlation coefficient between $S$ and Fe reached 0.71 , suggesting that they mainly occurred in the form of pyrite, which was found from the mineral analysis results of $3,6,9$, and 17\# samples (Table 2).

The XRD analysis of LTA showed that (Table 2), 15\# coal seam in Southeast Shanxi had major minerals including clay mineral (kaolinite, illite and montmorillonite) and quartz, and minor minerals including calcite, dolomite, pyrite, white mica, siderite and anatase. The clay had the highest mineral concentration and relative concentration above $70 \%$ generally, and it mainly included kaolinite and illite. To more systematically understand five harmful micro elements and relationship between different mineral, the correlation between $\mathrm{Hg}, \mathrm{Cr}, \mathrm{Se}, \mathrm{Pb}$ in the form of inorganic matters and main inorganic minerals were analyzed. 
Citation: Li D, Wang D, Wang Y, Ren C, Yuan N (2017) Occurrence and Environmental Features of Heavy Metal Elements of Coal from Coalfield in the Southeast Shanxi. J Environ Anal Toxicol 7: 483. doi: 10.4172/2161-0525.1000483
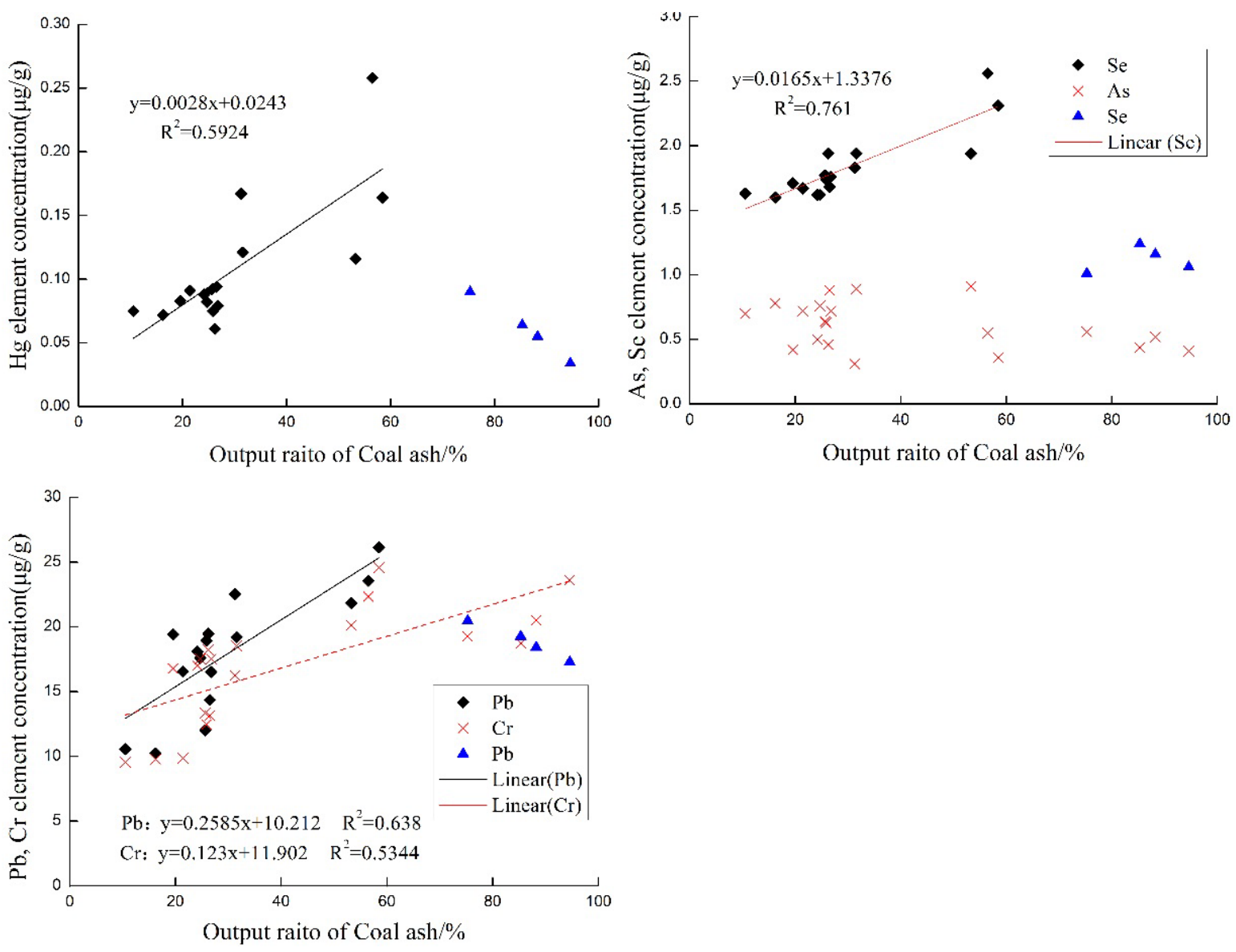

Figure 3: Correlation between heavy metal element concentration and output ratio of coal ash.

It could be seen from Table 5 that $\mathrm{Hg}$ was not only highly correlative with $\mathrm{S}$ and $\mathrm{Fe}$, but also significantly correlative with main elements in clay mineral, $\mathrm{Al}, \mathrm{Si}, \mathrm{K}$, and $\mathrm{Na}$, so it can be concluded that $\mathrm{Hg}$ closely related to pyrite, and very closely related to clay mineral; although the correlation coefficient between $\mathrm{Hg}$ concentration and P concentration reached 0.90 , but no phosphonium-containing mineral, such as apatite, cryptolite, xenotime, etc., was founded. Figure 4 shows that $\mathrm{Hg}$ was very positively correlative with pyrite, and $\mathrm{Hg}$ concentration closely related to kaolinite unless otherwise in coal seam roof and floor (peat), with the correlation coefficient as high as 0.77 . Figure 5 shows energy dispersive spectra under a scanning electron microscope. Hg element was founded in pyrite and clay mineral, indicating that $\mathrm{Hg}$ closely related to pyrite and clay mineral from the angle of energy dispersive spectra.

It could be known from Table 5 that $\mathrm{Cr}$, $\mathrm{Se}$ and $\mathrm{Pb}$ were not significantly correlative with macroelements, for example, the correlation coefficients between them and $\mathrm{Al}, \mathrm{Si}, \mathrm{K}$, and $\mathrm{Na}$ were $0.41 \sim 0.59$, indicating a weak correlation. Figure 4 shows $\mathrm{Pb}$ and $\mathrm{Cr}$ elements were significantly correlative with kaolinite, with their correlation coefficients of 0.49 and 0.77 , respectively; and not significantly correlative with the other minerals; Se element closely related to kaolinite unless otherwise in the roof and floor (peat), and was correlative with illite, with the correlation coefficients of 0.84 and 0.65 , respectively. $\mathrm{Se}, \mathrm{Cr}$ and $\mathrm{Pb}$ mainly occurred in kaolinite, and Se also occurred in illite. The correlation coefficient between $\mathrm{Hg}$ and $\mathrm{Se}$ was 0.72 , and Se was weakly correlative with $\mathrm{Al}, \mathrm{Si}, \mathrm{K}$, and $\mathrm{Na}$, so it was concluded that $\mathrm{Hg}$ and Se coexisted possibly in clay mineral. It was found from the energy dispersive spectra under a scanning electron microscope that $\mathrm{Hg}$ and Se exited in clay mineral (Figure 5), indicating that Se occurred in clay mineral from the angle of energy dispersive spectra.

\section{Heavy metal element loss rate}

Five heavy metal elements were volatile, so they easily entered air during coal combustion and led to air pollution and human health hazards [11,12]. To further understand their potential hazards, HTA $\left(850^{\circ} \mathrm{C}\right)$ was tested on its element concentration. Five elements concentrations in HTA are listed in Table 3. The loss rates of five elements were calculated (Figure 6). It could be known from Figure 6 that $\mathrm{Hg}$ loss rate was the highest, $99.43 \%$ on average, and higher in each layer; $\mathrm{As}, \mathrm{Se}, \mathrm{Cr}$ and $\mathrm{Pb}$ loss rates were $85.91 \%, 77.89 \%, 73.81 \%$ and $68.85 \%$, respectively; As and Se loss rates were very large, above $90 \%$, in $4 \sim 8$ and 11 16\# samples (Figure 7).

Except from As, the target elements closely related to clay mineral. $\mathrm{Hg}$ main occurred in pyrite. Different heavy metal elements occurred very differently, and had significantly different loss rate at the same temperature. During coal combustion, minerals in coal were converted under heating. For example, kaolinite always converted to metakaolin, akerite and mullite at about $600^{\circ} \mathrm{C}, 900^{\circ} \mathrm{C}$ and $1200^{\circ} \mathrm{C}$, respectively; in this process, water was lost, mother crystal structure was destroyed and chemical bonds were broken, resulting in release of the microelements in the adsorption state or in crystal interfaces [15]; pyrite was converted to hematite or magnetite at about $500^{\circ} \mathrm{C}$, whereas calcite, siderite decomposed into calcium oxide and iron oxide at $800^{\circ} \mathrm{C}$ [30], so 
Citation: Li D, Wang D, Wang Y, Ren C, Yuan N (2017) Occurrence and Environmental Features of Heavy Metal Elements of Coal from Coalfield in the Southeast Shanxi. J Environ Anal Toxicol 7: 483. doi: 10.4172/2161-0525.1000483
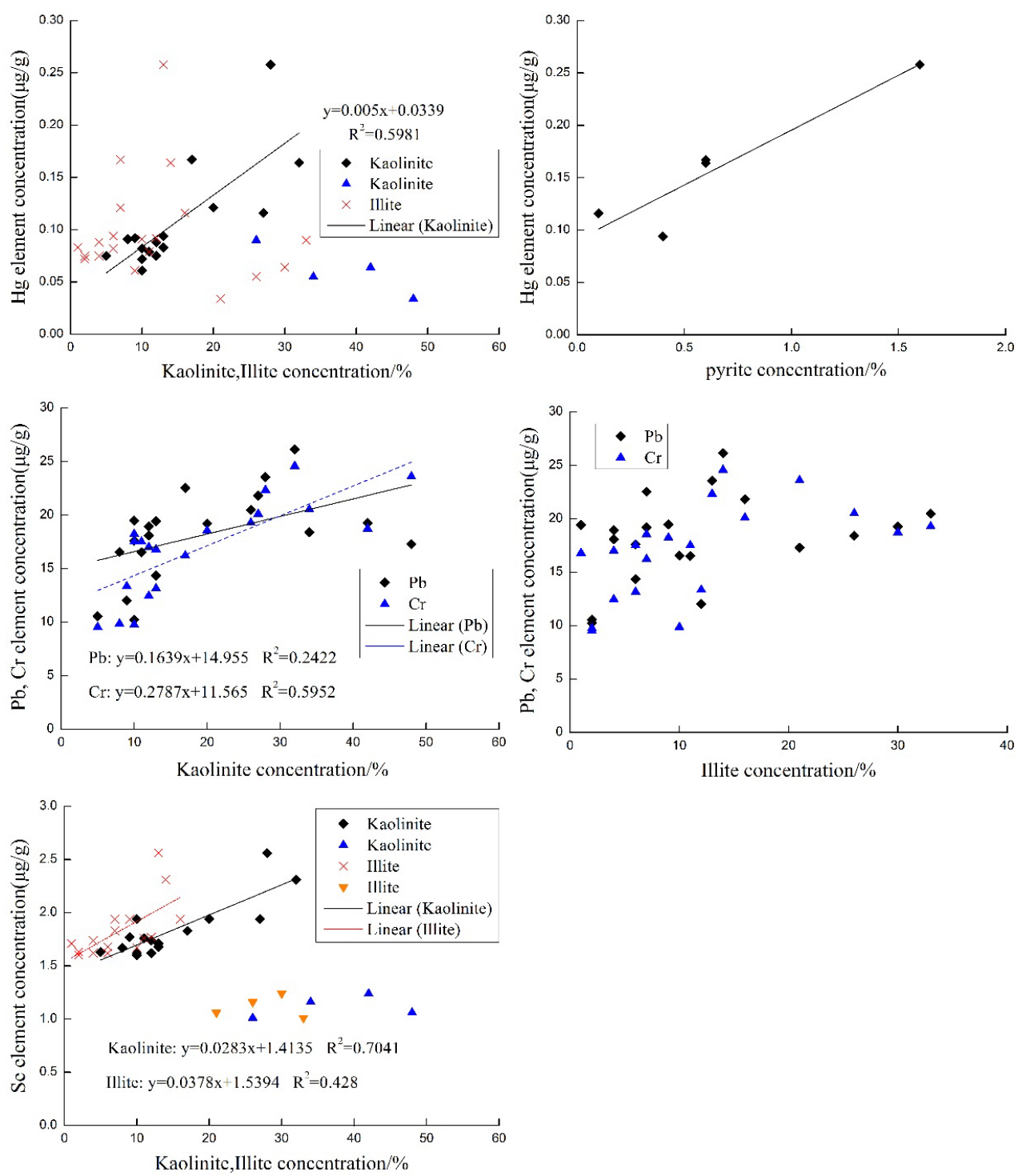

Figure 4: Correlation between mineral concentration and heavy metal element concentration.
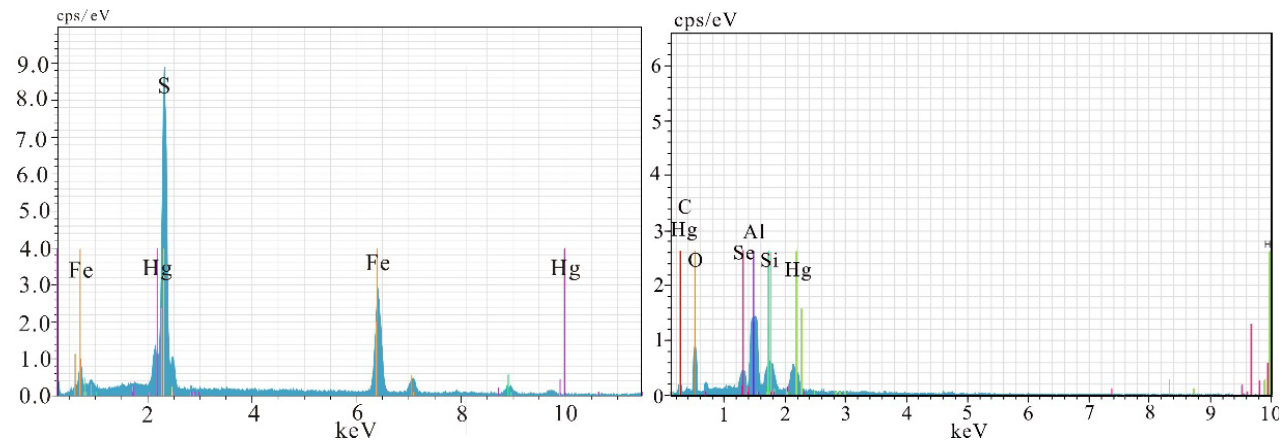

Figure 5: Elements in minerals from coal by SEM-EDX.

quick breakage of chemical bonds significantly accelerated release of isomorphous micro elements in mineral crystal [15]. Chemical bonds in pyrite were broken at low temperature $\left(500^{\circ} \mathrm{C}\right)$, and $\mathrm{Hg}$ existing in crystal interfaces and stagnant zone and in the isomorphous form was completely released, so $\mathrm{Hg}$ had higher loss rate; chemical bonds of clay mineral were broken at higher temperature [15]; clay mineral always 
Citation: Li D, Wang D, Wang Y, Ren C, Yuan N (2017) Occurrence and Environmental Features of Heavy Metal Elements of Coal from Coalfield in the Southeast Shanxi. J Environ Anal Toxicol 7: 483. doi: 10.4172/2161-0525.1000483

Page 7 of 8

\begin{tabular}{|c|c|c|c|c|c|c|c|c|c|c|c|c|c|c|c|}
\hline & $S$ & $\mathrm{Fe}$ & $\mathbf{S i}$ & Al & $\mathrm{Na}$ & $\mathrm{Ca}$ & $\mathbf{M g}$ & $K$ & $\mathbf{P}$ & $\mathrm{Ti}$ & $\mathrm{Hg}$ & $\mathrm{Cr}$ & As & $\mathrm{Se}$ & $\mathrm{Pb}$ \\
\hline$S$ & 1 & & & & & & & & & & & & & & \\
\hline $\mathrm{Fe}$ & 0.71 & 1 & & & & & & & & & & & & & \\
\hline Si & -0.52 & -0.62 & 1 & & & & & & & & & & & & \\
\hline Al & -0.35 & -0.58 & 0.94 & 1 & & & & & & & & & & & \\
\hline $\mathrm{Na}$ & -0.61 & -0.65 & 0.73 & 0.72 & 1 & & & & & & & & & & \\
\hline $\mathrm{Ca}$ & 0.41 & 0.58 & -0.76 & -0.74 & -0.74 & 1 & & & & & & & & & \\
\hline $\mathrm{Mg}$ & -0.58 & -0.67 & 0.78 & 0.78 & 0.98 & -0.77 & 1 & & & & & & & & \\
\hline K & -0.74 & -0.68 & 0.83 & 0.75 & 0.83 & -0.76 & 0.83 & 1 & & & & & & & \\
\hline $\mathbf{P}$ & 0.57 & 0.77 & -0.63 & -0.34 & -0.52 & 0.55 & -0.55 & -0.67 & 1 & & & & & & \\
\hline $\mathrm{Ti}$ & 0.10 & -0.02 & 0.08 & -0.09 & -0.03 & -0.14 & 0.14 & -0.07 & -0.12 & 1 & & & & & \\
\hline $\mathrm{Hg}$ & 0.65 & 0.77 & 0.63 & 0.63 & 0.62 & 0.58 & 0.60 & 0.66 & 0.90 & 0.25 & 1 & & & & \\
\hline $\mathrm{Cr}$ & 0.38 & 0.27 & 0.44 & 0.44 & 0.43 & 0.23 & 0.41 & 0.30 & 0.42 & -0.27 & 0.29 & 1 & & & \\
\hline As & -0.36 & -0.24 & 0.26 & 0.22 & 0.15 & -0.22 & 0.12 & 0.20 & -0.38 & 0.18 & -0.09 & -0.43 & 1 & & \\
\hline $\mathrm{Se}$ & 0.51 & 0.23 & 0.57 & 0.59 & 0.56 & 0.22 & 0.54 & 0.57 & 0.53 & 0.26 & 0.72 & 0.08 & -0.08 & 1 & \\
\hline $\mathbf{P b}$ & 0.45 & 0.25 & 0.44 & 0.46 & 0.42 & 0.27 & 0.43 & 0.46 & 0.52 & -0.30 & 0.56 & 0.76 & -0.46 & 0.47 & 1 \\
\hline
\end{tabular}

Table 5: Correlation coefficients between inorganic macroelements and between inorganic macroelements and heavy metal elements in coal.

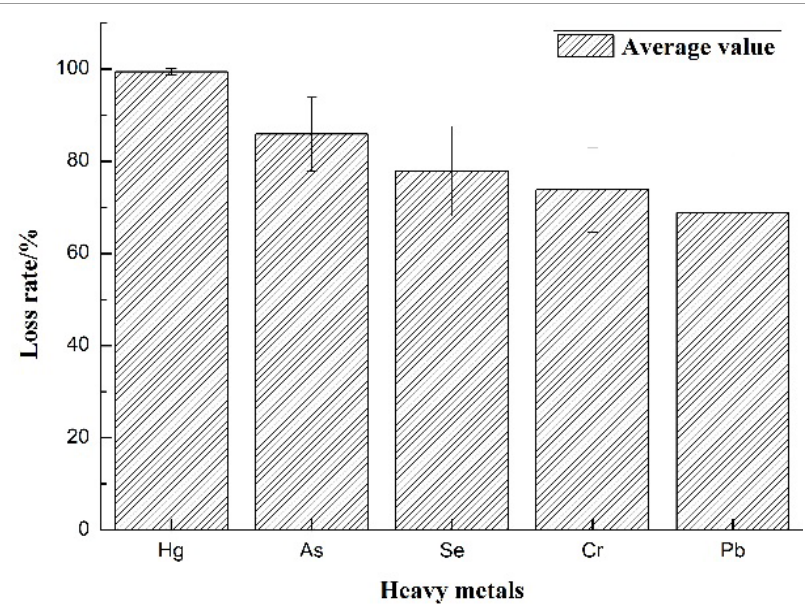

Figure 6: Average loss rate of each heavy metal element.

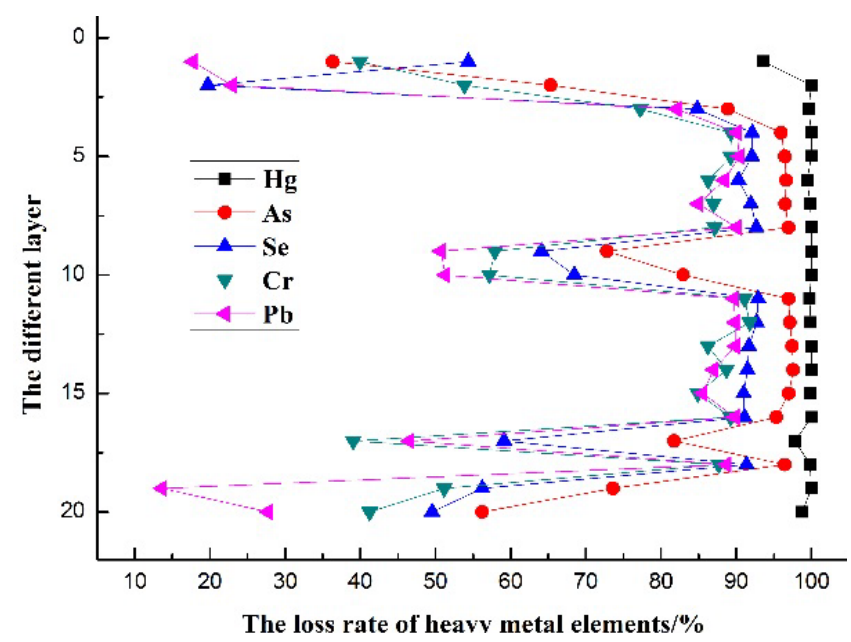

Figure 7: Heavy metal element loss rate in each layer.

was converted to metakaolin and akerite at about $800^{\circ} \mathrm{C}$ [15], and its chemical bonds were partially broken to mainly release the micro elements in the adsorption state or in crystal interfaces and minorly release isomorphous micro elements, so its loss rate was relatively low.

\section{Conclusions}

(1) 15\# coal seam in Coalfield in Southeast Shanxi had Hg element concentration between $0.044 \sim 0.268 \mu \mathrm{g} / \mathrm{g}, 0.11 \mu \mathrm{g} / \mathrm{g}$ on average; As element concentration between $0.31 \sim 0.91 \mu \mathrm{g} / \mathrm{g}, 0.61 \mu \mathrm{g} / \mathrm{g}$ on average; $\mathrm{Se}$ element concentration between $0.94 \sim 3.56 \mu \mathrm{g} / \mathrm{g}, 2.45 \mu \mathrm{g} / \mathrm{g}$ on average; $\mathrm{Cr}$ element concentration between $9.54 \sim 24.58 \mu \mathrm{g} / \mathrm{g}, 17.06 \mu \mathrm{g} / \mathrm{g}$ on average; $\mathrm{Pb}$ element concentration between $10.23 \sim 23.56 \mu \mathrm{g} / \mathrm{g}, 18.13 \mu \mathrm{g} / \mathrm{g}$ on average. Compared with Clark value, Se was enriched very much, As and $\mathrm{Cr}$ were lost, and $\mathrm{Hg}$ and $\mathrm{Pb}$ concentrations were normal in the coal from 15\# coal seam in Coalfield in Southeast Shanxi. Compared with the element concentrations in coals from other regions both at home and abroad, $\mathrm{Hg}$, $\mathrm{Se}, \mathrm{Cr}$, and $\mathrm{Pb}$ concentrations were normal and as was lost in 15\# coal seam in Coalfield in Southeast Shanxi.

(2) Five heavy metal elements concentrations were significantly different in the coal seam cross section, significantly high in the baulk layer, and vertically irregular; in spite of significant difference in element concentrations between adjacent layers, no significant enrichment occurred.

(3) Correlation between five heavy metal elements and ash and inorganic elements, mineral concentrations in LTA and SEM-EDX spectra of mineral particles showed that $\mathrm{Hg}$ closely related to pyrite and clay mineral; $\mathrm{Se}, \mathrm{Cr}$ and $\mathrm{Pb}$ mainly occurred in clay mineral kaolinite, and Se also occurred in illite.

(4) Five heavy metals occurred in different minerals or existing in the adsorption state, in crystal interfaces and stagnant zone and in the isomorphous form one mineral at different proportions. After treatment at high temperature, the average $\mathrm{Hg}, \mathrm{As}, \mathrm{Se}, \mathrm{Cr}$ and $\mathrm{Pb}$ loss rates were $99.43 \%, 5.91 \%, 77.89 \%, 73.81 \%$ and $68.85 \%$, respectively.

\section{References}

1. Zhang J, Ren D, Zhu Y, Chou CL, Zeng R, et al. (2004) Mineral matter and potentially hazardous trace elements in coals from Qianxi Fault Depression Area in south-western Guizhou, China. International Journal of Coal Geology 57: 49-61.

2. Dai S, Ren D, Ma S (2004) The cause of endemic fluorosis in western Guizhou Province, Southwest China. Fuel 83: 2095-2098.

3. Dai S, Ren D, Tang Y, Yue M, Hao L (2005) Concentration and distribbution of elements in Late Permian coals from western Guizhou Province, China. International Journal of Coal Geology 61: 119-137.

4. Dai S, Ren D, Chou CL (2012) Geochemistry of trace elements in Chinese 
Citation: Li D, Wang D, Wang Y, Ren C, Yuan N (2017) Occurrence and Environmental Features of Heavy Metal Elements of Coal from Coalfield in the Southeast Shanxi. J Environ Anal Toxicol 7: 483. doi: 10.4172/2161-0525.1000483

Page 8 of 8

coals: A review of abundances, genetic types, impacts on human health, and industrial utilization. International Journal of Coal Geology 94: 3-21.

5. Finkelman RB (2004) Potential health impacts of burning coal bed and waste banks. International Journal of Coal Geology 59: 19-24.

6. Chen J, Liu GJ, Jiang MM (2011) Geochemistry of environmentally sensitive trace elements in Permian coals from the Huainan coalfield, Anhui, China. International Journal of Coal Geology 88: 41-45.

7. PECH (1981) Trace-Elements geochemistry of coal resource development related to environmental quality and health. Washington DC, National Academy Press, p: 153.

8. Swaine DJ, Goodarzz F (1995) Environmental aspects of trace elements in coal. Kluwer Academic Publishers, pp: 1-60.

9. Wong CS, Li X, Thornton I (2006) Urban environmental geochemistry of trace metals. Environ Pollut 142: 1-16.

10. Dabrowski JM, Ashton PJ, Murry K (2008) Anthropogenic mercury emission in South Africa: Coal combustion in powe plants. Atmospheric Environment 42: 6620-6626.

11. Tian HZ, Wang Y, Xue ZG (2011) Atmospheric emissions estimation of $\mathrm{Hg}$ As, and Se from coal-fire power plants in China, 2007. Science of the Total Environment 406: 3078-3081.

12. Chen J, Liu G, Kang Y, Wu B, Sun R, et al. (2013) Atmospheric emissions of $\mathrm{F}, \mathrm{As}, \mathrm{Se}, \mathrm{Hg}$, and $\mathrm{Sb}$ from coal-fired power and heat generation in China. Chemosphere 90: 1925-1932

13. EPA Technical Information (2000) EPA to regulate mercury and other air toxics emissions from coal and oil-fired power plants.

14. Li YB, Jiang B, Qu ZH (2014) Controls on migration and aggregation for tectonically sensitive elements in tectonically deformed coal: An example from the Haizi mine, Huaibei coalfield, China. Science China 44: 2419-2430.

15. Finkelman RB, Palmer CA, Krasnow MR, Aruscavage PJ, Sellers GA, et al. (1990) Combustion and leaching Behavior of Elements in the Argonne Premium Coal Samples. Energy Fuels 4: 55-58.

16. Eberl DD (2003) User's guide to rockjock-a program for determining quantitative mineralogy from powder x-ray diffraction data. US Geological Survey, OpenFile Report.

17. Liu GJ, Yang PY, Peng ZC, Wang GL (2003) Geochemistry of trace elements from the No.3 coal seam of Shanxi Formation in the Yanzhou mining district. Geochimica 32: 255-262.
18. Finkelman RB (1981) Mode of occurrence of trace elements in coal. US Geol Surv Open-file Report, pp: 81-99.

19. Finkelman RB (1994) Modes of occurrence of potentially hazardous elements in coals: levels of confidence. Fuel Processing Technology 39: 21-34.

20. Dvornikov AG (1981) Forms of mercury in Donets Basin coal. Geol Zh 41: 96104

21. Zhang JY, Ren DY, Xu WD (1999) The distribution of Mercury in Major Associated Minerals from Coal Beds in Southwestern Guizhou. Geological Review 45: 539-542.

22. Wang YQ, Ren DY, Wang LG (1996) Mode of occurrence of trace elements in coal. Coal Geology \& Exploration 24: 9-11.

23. Zhao FH (1997) Study on the Mechanism of Distribution and Occurrences of hazardous Minor and Trace Elements in Coal and Leaching Experiments of Coal Combustion Residues. Beijing: China University of Mining \& Technology, pp: 53-58.

24. Dai S, Ren D, Chou CL, Li S, Jiang Y (2006) Mineralogy and geochemistry of the No.6 coal (Pennsylvanian) in the Junger Coalfield, Ordos Basin, China International Journal of Coal Geology 66: 253-270.

25. Dai SF, Han DX, Chou CL (2006) Petrography and geochemistry of the Middle Devonian coal from Luquan, Yunnan Province, China. Fule 85: 456-464.

26. Dai S, Li D, Chou CL, Zhao L, Zhang Y, et al. (2008) Mineralogy and geochemistry of boehmite-rich coal: new insights from the haerwusu Surface Mine, Jungar Coalfield, Inner Mongolia, China. International Journal of Coal Geology 74: 185-202.

27. Wang J, Yamada O, Nakazato T, Zhang ZG, Suzuki Y, et al. (2008) Statistica analysis of the concentrations of trace elements in a wide diversity of coals and its implications for understanding elements modes of occurrence. Fuel 87: 2211-2222.

28. Sia SG, Abdullah WH (2011) Concentration and association of minor and trace elements in Mukah coal from Sarawak, Malaysia, with emphasis on the potentially hazardous trace elements. International Journal of Coal Geology 88: 179-193.

29. Riley KW, French DH, Farrell OP, Wood RA, Huggins FE, et al. (2012) Modes of occurrence of trace and minor elements in some Australian coals. International Journal of Coal Geology 94: 214-224.

30. Deyi R, Fenghua Z, Shifeng D (2006) Geochemistry of trace elements in coal Science Press, Beijing. 